\title{
Evaluating the performance of freight transport: a service approach
}

\author{
Corinne Blanquart • Antje Burmeister
}

Received: 18 September 2008 / Accepted: 6 October 2009/Published online: 29 October 2009

(C) European Conference of Transport Research Institutes (ECTRI) 2009

\begin{abstract}
Background and aim The objective of this paper is to develop an alternative framework for evaluation of performance in freight transport, based on heterodox service economics. Traditionally, transport performance is analysed through productivity measures, even though the conceptual, methodological and practical problems of these indicators are well established in the literature.

Methods The paper develops and applies a typology of transport service configurations. The empirical analysis uses data from a large scale transport survey and from case studies in France.

Result The result of this analysis is an array of performance indicators, each one corresponding to specific types of transport services.

Conclusion We conclude that there is not a single way of achieving performance in freight transport, but a variety of service configurations, each of them having a particular logic of performance.
\end{abstract}

Keywords Freight transport - Logistics · Services ·

Productivity $\cdot$ Performance $\cdot$ Evaluation

\section{Introduction}

Throughout the 20th century, freight transport has grown dramatically in France, as in all Western countries. Since World War II, freight flows in ton-km have grown by factor 5 . One specific mode of transport has more particularly

\footnotetext{
C. Blanquart $\cdot$ A. Burmeister $(\bowtie)$

INRETS-SPLOTT,

BP 317, 59666 Villeneuve d'Ascq Cedex, France

e-mail: antje.burmeister@inrets.fr

URL: http://www.inrets.fr/ur/splott/equipe.html

C. Blanquart

e-mail: corinne.blanquart@inrets.fr

URL: http://www.inrets.fr/ur/splott/equipe.html
}

benefitted from this growth: road haulage. On the contrary, the share of rail transport which had dominated freight transport for more than a century has fallen continuously since the 1950s. This evolution is common to all Western countries, but is even more accentuated in France.

The dominance of road haulage in freight transport is an important issue of public debate. This transport mode is often criticized for its negative external effects (pollution, accidents, congestion, ...). Despite a clear political will (as well on the national as on the European level) to correct the modal split, the trend appears to be difficult to stop, given the difference in infrastructure costs and the difficulties of alternative modes to adapt to the current trends in production systems.

Can we conclude from these long term trends that the economic performance of road transport is higher than in other transport modes? In this paper, we will argue that the answer to this debate depends on how performance is defined.

Economic performance is usually analysed in terms of productivity $[2,3,11]$, defined as the ratio between output (the volume of goods or services produced) and input (the volume of production factors used in the production process of these goods and services). The output of freight transport is generally measured in terms of physical units (tons or units forwarded, ton-kilometres etc.) or in terms of value (turnover). Production factors are measured in terms of personnel and vehicles [29, 33, 36, 39-41].

The technical and conceptual limitations of productivity measures in general are well known [24]. In the field of freight transport, a major problem is the measurement of the output of transport services, which is generally the ton-km. Transport specialist generally agree that the ton- $\mathrm{km}$ is not a satisfactory measure for the output of freight transport services, given the variety of modes and services. Nevertheless, the statistical apparatus in ministries of transport usually relies solely on these measures $[4,7,14,35]$.

Furthermore, physical transport operations become more and more integrated into complex logistic systems. Beyond 
transport operations, strictly speaking, transport firms deliver various services of management of flows, input to (and sometimes also management of) information systems, copacking, co-manufacturing etc. The performance of physical transport operations thus depend on the close interrelations with manufacturing systems, logistics management and information and communication systems [10, 18, 37], which cannot be analysed by the means of productivity indicators only.

Another problem is that material capital (infrastructure, rolling stock, information and communication systems) is generally considered to be the main production factor in transportation. Strategies to improve performance thus rely mainly on investment in infrastructures, equipment, transport technologies and ICT development.

In this paper, we analyse the limitations of productivity indicators from a service economics perspective. The concept of "service relation" allows us to take into account the specific human and relational dimension of "co-production" of transport services as well as the heterogeneity of demand of freight transport services which calls for a multidimensional framework of performance.

The underlying assumption is that there is not a single way of achieving efficiency in freight transport (as in any other service), but a variety of transport services, each of them having a particular logic of performance.

The empirical analysis in the paper is based upon a large-scale national survey of freight transport operations in France (ECHO) and on a small-scale qualitative firm survey in the Nord-Pas-de-Calais region. Through the breakdown of transport services in elementary units and their precise description, combined with the analysis of the strategies of all actors involved in the supply chain, we will describe the different configurations of freight transport and their articulation with the production system.

\section{A service economics perspective on freight transport performance}

From the perspective of service economics, two series of problems appear when evaluating the performance of services:

- Problems related to the specific user-producer interaction in services.

- Problems related to the measurement of production in service activities.

When applied to the case of freight transport, the conceptual framework of service economics allows us to specify the service relation between shippers and transport firms by describing the variety of freight transport demand, and to specify the "product" of transport in terms of short term output and long term 'outcome'.
2.1 Transport services defined in the framework of specific service relations

The definition and delimitation of activities creates a first series of analytical problems. As a matter of fact, freight transport can be internalised in an industrial activity, or an externalised service activity. If we define freight transport as a service activity, we can turn to the service literature which has attempted to characterize the specificities of services in general.

According to the standard technical definition, which can be traced back to the classical view of "unproductive services" (Smith, Marx), a service is considered as immaterial, co-produced between user and producer, nonstorable, and non-transportable.

Hill [27] criticizes the distinction between material goods and "intangible" services. Defining services by their intangibility introduces confusion, and the category of intangibles should be recognized as a type of good. Hill thus suggests making a distinction between three categories: tangible goods, intangible goods, and services. The two essential characteristics of services are that they "...cannot be produced without the agreement, co-operation and possibly active participation of the consuming unit" and that "the outputs produced are not separate entities that exist independently of the producers or consumers" ([27], p. 128).

Following Hill [26], the definition of services was further developed in a more socio-technical approach, focusing on the concept of "service relation". A service relation is considered as a particular social relation between a producer and a user, leading to a change in the status of a reality owned by the user. Service activities can thus be defined as operations aimed at the transformation of the state of a reality $\mathrm{C}$, performed by a service provider A for a user or client $\mathrm{B}$, the result of which is not an independent product which can circulate separately from the reality C [19].

The concept of 'service relation' thus makes it difficult to identify a 'standard service' in freight transport. The physical transfer of goods in space (measured in terms of ton- $\mathrm{km}$ ) is only one aspect of a service relation which is specific to a shipper and a carrier.

We can easily observe that freight transport operations have become more and more complex and differentiated over the past 30 years. Beyond shipping and handling goods, they more and more often include operations such as the treatment of information flows, the differentiation of goods for the final customer etc. The conceptual representation of freight transport exclusively in terms of flows of goods thus becomes less and less relevant to the realities of the freight transport sector and its performance issues. A more relevant conceptual representation of the 'product' of freight transport must include these different operations $[30,31]$. 
Nevertheless, even in the service economics literature, freight transport is generally considered as a standard, simple and material service, that is to say having a material object. Following Gadrey's [19] definition of services, different objects of services can be distinguished: material objects, people, or information. According to this typology of services, freight transport clearly belongs to the first category, moving material objects in space.

Similarly, in Du Tertre's $[15,16]$ typology of production systems ("configurations productives"), freight transport would belong to logistic services, the productivity of which is mainly determined by direct intensity of labor, scale economies and material integration.

Djellal [12] discusses the distinction between services dealing with information and "non-informational" services and demonstrates, in particular for road haulage services, the co-existence of material configurations with a growing integration of information, methodological and relational aspects. The introduction of information and communication technologies (ICT) has transformed the nature of these services $[1,13,21,23,28]$.

In a previous paper [8], we have discussed the coexistence of different types of operations in freight transport services. Following Gadrey [19] and Gallouj [22], we distinguish four types of operations in freight transport: material operations (the basic object of transport), treatment of (codified) information, relational or contact operations, and methodological operations (Table 1).

Material operations (M) concern mainly the traditional purpose of freight transport: shipping objects from one point in space to another, as well as handling of goods, loading and unloading. More recently, however, transport service providers sometimes provide other material services such as warehousing, packaging and labeling.

The diversity of potential combinations illustrates the fact that transport services, as all types of services, are heterogeneous products. Moreover, the array of combina- tions changes over time, which makes it impossible to analyse the dynamics of the freight transport sector through the measurement of a standard service.

Even the most orthodox analyses in transport economics admit that ton- $\mathrm{km}$ are an obsolete measurement of the output of freight transport. Quite obviously, transport activities do not produce weights nor distances. Ton-km only measure the physical labour of transferring goods in space, which was probably the major preoccupation of carriers at the beginning of the 20th century, when $90 \%$ of goods were transported on rail and waterways. According to Fritsch and Prud'Homme ([17], p. 7), «the ancient and wide-spread habit of using ton- $\mathrm{km}$ continues in spite of the diversification of transport modes and transport services».

As a matter of fact, the ton-km remains, at the same time, the most widely criticized and most wide-spread indicator of output of the freight transport sector, which leads to an erroneous representation of freight transport performance. A correct and robust representation of 'output' of freight transport should take into account all the relevant service operations performed on the goods forwarded.

2.2 Transport is a process : the importance of the temporal dimension

If services produce a 'change of state', it becomes difficult to distinguish between product and process. Moreover, the temporal dimension of the change of state produced by a service is crucial. The more recent service economics literature distinguishes between 'output' and 'outcome' or 'immediate' outputs and 'mediate' outputs [20]. In the health sector, for example, indicators of output could be the number of medical acts performed, the number of days of hospitalization etc. whereas the outcome could be measured by a change in life expectancy; similarly, educational services can be evaluated by their output (number of students, number of

Table 1 The variety of operations coexisting in freight transport services

\begin{tabular}{|c|c|c|c|c|}
\hline & Material operations (M) & $\begin{array}{l}\text { Treatment of } \\
\text { information (I) }\end{array}$ & $\begin{array}{l}\text { Relational and contact } \\
\text { operations (R) }\end{array}$ & $\begin{array}{l}\text { Methodological } \\
\text { operations (C ) }\end{array}$ \\
\hline $\begin{array}{l}\text { Operations } \\
\text { concerning : }\end{array}$ & $\begin{array}{l}\text { Physical transport, } \\
\text { handling, loading, } \\
\text { unloading }\end{array}$ & $\begin{array}{l}\text { Treatment of information } \\
\text { flows inside the firm } \\
\text { and with other firms, } \\
\text { tracing/tracking }\end{array}$ & $\begin{array}{l}\text { Direct contacts between the } \\
\text { driver and the shipper's } \\
\text { customers, feedback on } \\
\text { quality of products and } \\
\text { distribution }\end{array}$ & $\begin{array}{l}\text { Coordinate and organize the } \\
\text { different operations ; find } \\
\text { necessary competencies }\end{array}$ \\
\hline $\begin{array}{l}\text { Improvement of } \\
\text { performance } \\
\text { through : }\end{array}$ & $\begin{array}{l}\text { Innovations in vehicles, } \\
\text { automation of handling } \\
\text { etc. }\end{array}$ & $\begin{array}{l}\text { Use of ICTs, creation } \\
\text { and optimisation of } \\
\text { information systems, } \\
\text { optimization of } \\
\text { management of freight } \\
\text { flows and fleet }\end{array}$ & $\begin{array}{l}\text { Training for drivers and } \\
\text { personnel, codification of } \\
\text { quality control systems }\end{array}$ & $\begin{array}{l}\text { Creation and improvement of } \\
\text { management systems of goods } \\
\text { and information for the shipper }\end{array}$ \\
\hline
\end{tabular}

Burmeister/Djellal [8] 
Fig. 1 Indicators of immediate output vs. outcome of freight transport services

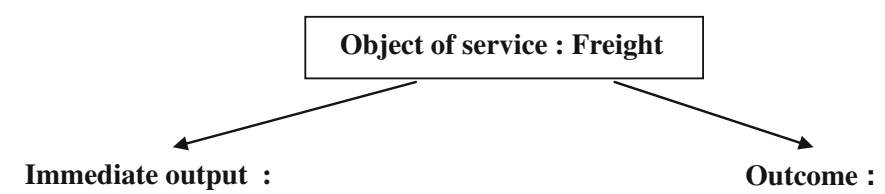

Handling of goods (number, volume, weight);

Distances covered ;

Tons or volumes forwarded ;

Etc.
- Geographical area covered

- Production capacity

- Safety and security ;

- Reliability

- Punctuality ;

- Just-in-time;

- Flexibility;

- Contribution to information flow management

- Adaptation to production constraints

- Etc. teachers of teaching hours), or by their outcome, for instance the level of education in a given population.

This distinction between output and outcome can be applied to freight transport services. The output of freight transport simply concerns the goods transported from one point in space to another. The outcome of freight transport services, however, goes far beyond this aspect of moving goods in space and concerns its contribution to an efficient supply chain on the whole, in terms of constant adaptation to the production system, just-in-time delivery, flexibility, reliability and input to the information and management system of the whole supply chain.

The usual productivity indicators based on ton- $\mathrm{km}$ thus only evaluate the immediate output of freight transport services. On the other hand, the outcome of these services, which is related to the efficiency of the articulation between the freight transport system and the production system for the goods to be forwarded, is not measured in the traditional indicators. In order to evaluate long-term performance, it is necessary to go beyond the single quantitative indicator and to develop a multicriteria framework taking into account the qualitative aspects of performance.

Fritsch and Prudhomme ([17], p. 17) recognize the difficulty to take into account the "quality of service" of freight transport. We think, on the contrary, that the dimensions of quality of service can be defined and are even quite well known - just-in time delivery, reliability, safety, sufficient production capacity (cf. Fig. 1 above)but that the problem of evaluation is related to the restriction of the evaluation framework to a single quantified indicator (such as the ton-km).

The analysis of freight transport performance should be related to the industrial production system in which the transport service takes place. In the management literature, logistic performance is more and more often measured in terms of customer satisfaction $[32,34]$ - not simply from the point of view of the shipper, but with regard to the global supply chain. Freight transport performance indicators should encompass the global efficiency of flows of goods and information inside a production system. In such a framework, the main levers to improve performance are the qualitative and quantitative adaptation to production systems instead of mere cost reduction and investments in vehicle technology or infrastructures.

\subsection{The main source of performance of freight transport} services lies in their articulation with the production system

This analytical framework also sheds a different light on the recent evolution of freight transport and logistics in France. The rapid development of road haulage compared to the "heavy" modes of freight transport cannot only be explained by its productivity, nor by regulatory and technical constraints, as it is often debated in France. The type of transport services that this mode delivers appears to be particularly well fitted to the organizational and market structure changes that began in the 1970s. In an environment of rising differentiation of consumption goods, shortened life cycles of products and just-in-time production, logistic management systems become a strategic function in production systems. In this context, road haulage becomes the most efficient mode of transport for frequent, rapid and flexible deliveries, in comparison to railroads and waterways, far more competitive for largescale transport flows of heavy or bulk goods. Trucks became, in a way, the symbol of the post-fordist accumulation regime.

In the 1990s, the structural changes in production and distribution methods lead to a reorganization of logistic and transport systems, in particular through the development of global supply chain management, involving producers, 
large-scale retailers, and logistic integrators in collaborative logistic processes. Freight transport services become part of more and more complex logistic processes, and transport firms cover a large variety of situations, from third party logistic providers who also provide transport services, to highly specialized companies, or very small scale subcontracting firms.

The adoption and development of information and communication technologies in freight transport, such as EDI (electronic data interchange) and web EDI, GPS, RFID (radio-frequency identification) etc., and the development of new methods of organizing logistics, information and transport flows (tracking and tracing methods, cross docking hubs, etc.) transform logistic processes in general and freight transport services in particular.

As a result, freight transport services, and in particular road haulage services, are nowadays far more complex than transporting a good from point $\mathrm{A}$ to point $\mathrm{B}$. We will illustrate this point in the second part of the paper.

To sum up, the traditional productivity indicators used in transport analyses, mostly based on the ton- $\mathrm{km}$ as a measure of output, only evaluate a direct, short term output. Firstly, these indicators only include a specific type of service-transfer of goods from one point to another in space - and exclude all other service operations that have become more and more important in the freight transport industry in the recent past. Secondly, freight transport produces other results on the long run, and in particular important impacts on the efficiency and long term evolution of industrial production systems which are simply not accounted for in quantitative productivity indicators, although they become more and more critical in terms of sustainability of the systems of production and circulation of goods.

In the second part of the paper, we will illustrate and apply a more comprehensive and qualitative framework of evaluation of service performance.

\section{An empirical analysis of freight transport performance in France}

\subsection{Methodology}

The empirical data used in this analysis were collected in two different surveys:

1. A large-scale survey named ECHO ("Enquête CHargeurs-Opérateurs", Survey Shipper-Carrier), carried out by INRETS in France in 2005 [25].

The goal of the ECHO survey was, on the one hand, to better understand the determinants of freight transport demand on the shipper's side (taking explicitly into account the specific constraints of production systems and the diversity of practice across industries), in particular the criteria for choosing transport modes, and, on the other hand, to fully describe 'transport chains' from origin to final destination as well as the different actors participating in the chain (shippers, carriers, shipping agents, brokers, consignees, final customers, warehouses, logistic service providers etc.). The survey was carried out on a very large scale, with a sample of over 3,000 production plants, carrying out approximately 10,000 shipments (the basic unit of observation) ; 25,000 persons participating in the shipments were interviewed, and about 17,000 detailed routes were described.

Such a rich and detailed empirical material is an important breakthrough for qualitative and quantitative analysis of freight transport and does not, to our knowledge, exist for other European countries. ${ }^{1}$ This survey is particularly interesting for our research questions for three reasons:

- The data set allows us to relate the demand for freight transport to the economic characteristics of shippers ;

- The data set encompasses complete transport chains, from origin to the final destination, whereas most transport surveys describe at best single routes, but do not follow a good that undergoes several successive shipments in different vehicles or on different transport modes. We can thus follow the physical itinerary of the shipment.

- The data set also includes information on service operations other than physical transport and thus allows us to analyse the variety of logistic operations carried out in a given transport chain.

2. The second data set that we have used in our empirical analysis was collected in a small scale qualitative study of 50 shippers in nine different industries located in the North of France [9]

The shippers interviewed in this survey belong to the following industries: food, rubber, paper, printing, wood, textile, waste treatment, metalworking, chemicals and automobile repair. The qualitative information collected in this survey is a necessary complement to the ECHO survey. As such, it allows us to precisely characterize the service relation between shippers and transport firms and its articulation with the production system as a whole. With the help of these data, we can identify types of production

\footnotetext{
${ }^{1}$ A smaller-scale survey base on shippers (but not shipments) which is, in some partial aspects, comparable to the ECHO survey does exist for Germany at DLR Berlin ; cooperation for a future comparative analysis is under way.
} 
Table 2 Service operations other than transport performed on shipments

\begin{tabular}{llr}
\hline Type of operation & Service operations & \% of shipments (multiple answers possible) \\
\hline Material (M) & Freight consolidation & $43 \%$ \\
M & Customs clearance, air or ocean forwarding & $1 \%$ \\
M & Supply of containers, loading, unloading & $2 \%$ \\
M & Warehousing & $5 \%$ \\
M & Finalization, packaging and labeling of goods & $15 \%$ \\
Information (I) & Quality control of goods & $24 \%$ \\
I & Inventory and/or order management & $5 \%$ \\
I & Electronic tracing / tracking & $39 \%$ \\
I & Electronic proof of delivery & $24 \%$ \\
\hline
\end{tabular}

that call for specific logistic organisations and specific transport chains.

3.2 The variety transport service operations according to the ECHO survey

In the next table, we can analyze the breakdown of operations performed on shipments calculated from ECHO survey data. The upper part of the table concerns the material operations, starting from the more traditional freight transport operations, but including also operations of warehousing ( $5 \%$ on shipments), and, more surprisingly, operations of finalization, packaging and labeling of goods carried out by transport firms in $15 \%$ of the shipments. Table 2.

The lower half of Table 2 concerns information operations (I) and demonstrates that an important share of shipments undergo this type of service operations. For almost $40 \%$ of shipments, the transport company provides some form of electronic tracking and tracing, and electronic proofs of delivery for one quarter of all shipments.

The methodological type of operations-(C) in Gallouj's [22] addition to Gadrey's functional breakdown of service operations - concern operations of coordination and organization of freight flows and the logistic system on the whole. This type of operations cannot be identified in our ECHO data. The only indirect information we can use in this respect is the degree of contracting out logistic operations. According to our data base, while $94 \%$ of shippers in the survey contract out at least part of their transport operations, only $35 \%$ of shippers use logistic service providers outside the firm-in other terms, $65 \%$ of the shippers carry out logistic operations in-house.

In relational operations (R), according to Gadrey's typology, the object of the service operation is the customer himself, in a direct contact service. In our case of freight transport services, this type of operations is difficult, if not impossible, to identify, especially in large, codified data sets such as the ECHO survey. In our case studies in the Nord-Pas-de-Calais Region, we could however identify some cases where this type of operation applies. The object of the relational service operation is, in these cases, the relation between the shipper's and his customer, in which the transport firm plays a particular role. This is mainly the case for transport firms that operate frequent dedicated delivery tour type operations on a regular basis for a given shipper. The transport service provider has the only direct contact to the customer and can give important feedback on quality issues and customer satisfaction.

We can now identify four different service trajectories in freight transport services, summarized in Table 3 below.

This table can also be interpreted in dynamic terms, as the possible evolution of transport firms, from a simple material trajectory, towards more complex informational and methodological trajectories. A large share of firms, in particular small transport firms and subcontractors for large logistic providers, remain in a mainly material service trajectory. More and more transport firms, however, are forced, under pressure from their customers, to adopt information and communication technologies and to in-
Table 3 The variety of service trajectories in freight transport firms

\begin{tabular}{ll}
\hline & Service trajectories \\
\hline$(\mathrm{M})$ & Simple material service trajectory \\
$(\mathrm{M})+(\mathrm{I})$ & Informational service trajectory \\
$(\mathrm{M})+(\mathrm{I})+(\mathrm{C})$ or $(\mathrm{I})+(\mathrm{C})$ or $(\mathrm{C})$ & Complex methodological / informational trajectories \\
$(\mathrm{M})+(\mathrm{R})$ & Relational service trajectory \\
\hline
\end{tabular}


clude informational service operations. A small number of large scale transport and logistics services providers evolve towards a complex methodological and informational service trajectory, some of which even contract out all of their transport operations and concentrate on the management of logistic systems.

This evolution implies that performance of transport services cannot be evaluated through flows of goods only. The traditional productivity indicators evaluate only one aspect of performance. Performance indicators should integrate all relevant aspects of transport services. The comparison of transport modes should not be limited to material flows only. Consequently, public policies aiming at a shift towards more sustainable transport modes should not be directed exclusively towards the material conditions of mobility (infrastructure, rolling stock, transport technologies), but also towards the development of complex value added transport services in the more sustainable modes.

\subsection{The diversity of needs for freight transport}

The nature and the content of a freight transport service are developed in a specific service relation between a shipper and the transport firm. Through our qualitative survey of production and transport firms in Northern France, we can identify three different types of production systems and their corresponding main transport service operations.

Group 1: Industrial production and circulation-Material transport operations

This logic is dominant in intermediary goods, as well as in certain consumption goods, characterized by high potential economies of scale. (e.g. intermediary goods such as cereals, fibres, bulk chemicals, and metal products). Production is spatially concentrated. Flows of goods are massified, and transport costs remain an important decision factor. Transportation in this type of firms concerns largescale standardised flows of goods (often full truck loads, FTL), and can use different modes of transport, including the traditional "heavy" modes of rail and waterways. Transport is usually contracted out, and transport services remain almost strictly limited to material operations. Information flows take place more massively inside the firm (between plants and with headquarters), namely through computerised data exchange, than with other firms. EDI is not used in interactions with other firms, and in particular not with transport firms.

Group 2: Products determined by final demand-The rise of information operations

This group concerns consumption goods, especially those distributed by large scale retailers (such as clothing, beverages, fresh foods, etc.). A high degree of differentiation of goods leads to different logistic and transport strategies, based on consolidation of flows (mainly less-than-truck loads, LTL), JIT deliveries, service quality and adaptation to demand variations.

The main characteristic is the strong association of flows and goods and flows of information to ensure flexibility of production and distribution. The need for inter-firm coordination becomes important here, and EDI is used more often here than in other modes of production. A major factor in this mode of production appears to be the possibility to re-organise the logistic system frequently. This perhaps explains why we can note a trend towards contracting out of logistic services to third-party logistics providers.

Group 3: Products based on competencies, user-producer interactions, and service

Production relies on close interactions between producers and users, which restricts the potential for standardization and scale economies. This group is mainly composed of high technology investment goods and engineering. As opposed to the previous two cases, face-to-face contacts are extremely frequent and appear to be the most important mode of co-ordination in close co-operation between producers and users. Intensive use of telecommunication means can also be observed, except EDI, which is only marginal in this mode of production relying mainly on mutual adjustment. Frequent contacts, interpersonal networks, and more generally non-market interactions, are vital to build trust and reputation. Transport and logistics do not play a major strategic role for this type of product. Transport flows are usually small, or seldom, and sometimes carried out by the production firm itself.

In the summary Table 4, we label these three groups as the industrial, flexible, and professional types of production-circulation systems, in reference to Storper's and Salais [38] work on 'worlds of production'.

These empirical results show how diverse the needs for freight transport services are and to what extent this diversity is related to the nature of the production systems in which the transport service takes place. The nature of demand for the forwarded good is the single most important factor that explains the characteristics of the transport service. In other terms, the organisation of freight transport, and in particular the choice of a transport mode, is, at least to some extent, the result of production constraints. This also implies that the lesser performance of the more sustainable modes (i.e. other than road haulage) can, at least partly, be related to the lack of value added services in freight transport. 
Table 4 Articulation between modes of production and transport service trajectories

\begin{tabular}{|c|c|c|c|c|}
\hline Mode of circulation & Production & $\begin{array}{l}\text { Typical freight service } \\
\text { operations }\end{array}$ & Logistics & $\begin{array}{l}\text { Service trajectories in } \\
\text { freight transport }\end{array}$ \\
\hline \multirow[t]{3}{*}{$\begin{array}{l}\text { Industrial (eg: basic } \\
\text { chemicals) }\end{array}$} & Intermediary goods & \multirow[t]{3}{*}{$\begin{array}{l}M \text { (large-scale, standardized } \\
\text { flows, full loads FTL)) }\end{array}$} & $\begin{array}{l}\text { Industrial logistics, based on the } \\
\text { criterion of cost }\end{array}$ & $(\mathrm{M})$ \\
\hline & No differentiation & & Externalized transport & Tendency towards \\
\hline & $\begin{array}{l}\text { Economies of scale } \\
\text { Specialized production } \\
\text { plants }\end{array}$ & & $\begin{array}{l}\text { All transport modes, including } \\
\text { "heavy" modes }\end{array}$ & $(\mathrm{M})+(\mathrm{I})$ \\
\hline \multirow[t]{6}{*}{$\begin{array}{l}\text { Flexible (eg : } \\
\text { clothing, food) }\end{array}$} & Consumer goods & $\mathrm{I}$; sometimes $\mathrm{C}$ & $\begin{array}{l}\text { Sophisticated logistics (high- } \\
\text { speed transport }+ \text { EDI) }\end{array}$ & $(\mathrm{M})+(\mathrm{I})$ \\
\hline & \multirow[t]{5}{*}{$\begin{array}{l}\text { Mass production, but } \\
\text { differentiated }\end{array}$} & \multirow{5}{*}{$\begin{array}{l}\text { Association of frequent, rapid } \\
\text { and small-scale or consoli- } \\
\text { dated (LTL) flows of goods } \\
\text { and flows of information }\end{array}$} & $\begin{array}{l}\text { JIT production and/or } \\
\text { distribution }\end{array}$ & Tendency towards \\
\hline & & & $\begin{array}{l}\text { Main criteria: reliability (time, } \\
\text { quality) and flexibility } \\
\text { (frequent changes in logistic } \\
\text { organization) }\end{array}$ & $(\mathrm{M})+(\mathrm{I})+(\mathrm{C})$ \\
\hline & & & Mainly road haulage & $\begin{array}{l}\text { Tendency towards a } \\
\text { disintegration of } \\
\text { logistic operations } \\
\text { among service } \\
\text { providers }\end{array}$ \\
\hline & & & Third-party logistics & $(\mathrm{M}) /(\mathrm{I})+(\mathrm{C})$ \\
\hline & & & & $\begin{array}{l}\text { A few cases }(M)+ \\
(R)\end{array}$ \\
\hline \multirow[t]{4}{*}{$\begin{array}{l}\text { Professional } \\
\text { (eg : machinery, } \\
\text { engineering) }\end{array}$} & $\begin{array}{l}\text { Production of units or } \\
\text { very small scale of } \\
\text { production }\end{array}$ & M & Basic logistics, on a small scale & $(\mathrm{M})$ \\
\hline & Customized production & Small-scale flows of goods & $\begin{array}{l}\text { No contracting out of logistic } \\
\text { services }\end{array}$ & $\begin{array}{l}\text { In some cases }(M)+ \\
(R)\end{array}$ \\
\hline & \multirow{2}{*}{$\begin{array}{l}\text { Specific knowledge, } \\
\text { close user-producer } \\
\text { interactions }\end{array}$} & & Internalized transport operations & \\
\hline & & & Road haulage & \\
\hline
\end{tabular}

\subsection{The complexity of logics of performance}

It now becomes clear that the strategies to achieve performance in these different transport service configurations differ greatly. Optimization of physical transport operations is only a small part of the strategy, more important in the industrial mode of production, associated with the material transport service trajectory. In other words, the traditional evaluation of performance in terms of productivity, using ton- $\mathrm{km}$ as an indicator of output, can only be applied to one of the four service trajectories that we have identified (Table 5).

In the three other configurations, the achievement of performance relies on the management of information flows, on the improvement of information systems, and on the flexibility of the logistic system.

The reason for the transformation of transport service trajectories towards the inclusion of informational and methodological operations lies mainly in the pressure from shippers and the transformation of modes of production, in particular the development of more flexible mode of production, which rely heavily on flexible logistic systems and information flows.
An analysis of performance through synthetic productivity indicators based on ton-km thus needs to be put into a larger perspective: ${ }^{2}$ :

- It is no longer possible to use a single homogeneous representation of immediate output, since freight transport services have been diversified way beyond the simple transfer of goods in space;

- Productivity depends upon several interrelated factors :

- The actors that participate in the transport service relation (a social relation between the shipper, the carrier and the consignee, and sometimes other participants) ;

- The institutional context in which the service takes place, which we can characterize in terms of specific logics of production and circulation, as well as through the regulatory context of each actor.

\footnotetext{
${ }^{2}$ P. Bétard [5] attempted to construct a synthetic productivity index combining quantitative and qualitative aspects of road haulage services. However, his analysis appeared too difficult to apply at the macroeconomic level and was not pursued any further.
} 
Table 5 The complexity of logics of performance in freight transport services

\begin{tabular}{|c|c|c|c|}
\hline $\begin{array}{l}\text { Freight transport } \\
\text { service trajectory }\end{array}$ & $\begin{array}{l}\text { Association with } \\
\text { modes of } \\
\text { production }\end{array}$ & Logics of performance & $\begin{array}{l}\text { Possibility of quantitative } \\
\text { (productivity) indicators }\end{array}$ \\
\hline M & $\begin{array}{l}\text { Industrial } \\
\text { Professional }\end{array}$ & Optimization of physical transport operations (FTL) & yes \\
\hline \multirow[t]{3}{*}{$M+I$} & \multirow{3}{*}{$\begin{array}{l}\text { Flexible sometimes } \\
\text { Industrial }\end{array}$} & Optimization of consolidation of transport operations (LTL) & partial indicators \\
\hline & & Management of information flows & no \\
\hline & & Optimization of flexibility of logistics & no \\
\hline $\mathrm{M}+\mathrm{I}+\mathrm{C}$ & Flexible & $\begin{array}{l}\text { Improvement of management and information systems, development of } \\
\text { new management and information systems }\end{array}$ & no \\
\hline$M+R$ & $\begin{array}{l}\text { Professional } \\
\text { Flexible (few } \\
\text { cases) }\end{array}$ & $\begin{array}{l}\text { Improvement of coordination processes, quality of interactions, } \\
\text { establishment of trust, stabilization of relations (Interface role of } \\
\text { transport services) }\end{array}$ & no \\
\hline
\end{tabular}

Productivity indices can be useful for the industrial type of organisation of production which requires mainly basic transport services which are clearly identified and relatively stable.

When the organisation of production becomes more complex, productivity indices become less relevant for the evaluation of performance, since the overall performance is less related to the optimisation of transfer of goods in space and more and more to the functioning of relations throughout the supply chain.

In other words, productivity indices must be put into the perspective of the needs of circulation and transport of the production system.

Moreover, such a renewed framework reveals the need to differentiate the levers of performance in public policies towards freight transport. Beyond public actions directed towards mobility and the volume of flows, it appears to be necessary to strengthen the articulation between transport systems and the needs of the production system. In particular, this becomes crucial in policies that attempt to favour alternative transport modes (i.e. other than road haulage).

\section{Conclusion}

In this paper we have attempted to demonstrate that performance of freight transport, as for any other type of service, is a multidimensional concept, and that traditional productivity measures are unable to take into account the majority of the factors of performance. As a matter of fact, the evolution of productivity cannot explain the dramatic shift towards the use of road haulage vs. the traditional freight transport modes of railroads and waterways beyond the well known problem of external costs.

Conceptual frameworks developed in economics and management of services can greatly help to raise the understanding of the complexity of performance logics in freight transport and thus improve the methodologies used in transport ministries. We used the heterodox approach developed in service economics in two complementary ways: in order to understand the variety of operations that can be found in transport services, on the one hand, and in order to build a multidimensional framework of performance.

Our typology of freight transport operations identifies and describes different service trajectories which are based on material logistic operations, but can include to various degrees the treatment of information, contact operations, and methodological operations. This typology of freight transport trajectories gives a coherent description of the changes that the freight and logistics sector has undergone in the past 25 years - from moving heavy goods from A to $\mathrm{B}$ to managing complex logistic systems including a rising share of information flows.

In our view, the main source of performance of freight transport services lies in their articulation with the production system. In our empirical analysis based on the French case, we could relate specific modes of production of goods in the production system to specific service trajectories in freight transport and distribution logistics. This analysis shows that the greater complexity of freight transport services, which include informational operations and management, are to be found mainly in highly flexible production systems of differentiated consumption goods. The observed shift towards road haulage could be at least partly explained by its superior ability to adjust to flexible production systems.

Our analysis finally rejects the possibility of using a single quantified performance indicator and calls for a heuristic multidimensional framework of performance evaluation, combining a larger number of-potentially conflicting or double-counting-performance indicators. Several of these different definitions and indicators of 
performance conflict with each other-in particular performance logics referring to the industrial and the market logic with public policies pertaining to sustainable development objectives.

A further step in our research will be to integrate these different performance logics and criteria into a comprehensive framework-not with the objective to elaborate a single criterion of performance, but, on the contrary, to allow for comparative and contradictory analysis of performance logics of the different actors participating in the system of production and circulation of goodsdifferent types of shippers, of transport and logistic firms, and different kinds of public and private institutions taking part in the regulation of the system. Conventions theory, and in particular Boltanski and Thevenot's [6] framework of "worlds", or "orders of worth", as well as Salais and Storper's analysis of "worlds of production", shall be used in order to develop such a framework.

Our empirical research is limited to the French case, since detailed qualitative date are not available on a large scale for other countries. The traditional datasets available in transport statistics do not allow to establish the relation between transport services and the organization of production of shippers. Further empirical research will be undertaken, at least on smaller scale data sets, for example in Germany, in order to compare our results on the European level.

\section{References}

1. Barras R (1986) Towards a theory of innovation in services. Res Policy 15(4):161-173

2. Battese GE, Coelli T, Rao P (1998) An introduction to efficiency and productivity analysis. Kluwer Academic Publishers, Londres

3. Baumol W, Bowen WG (1965) On the performing arts: the anatomy of their economic problems. American Economic Review 55(1-2), March

4. Bernadet M, Ravet D (2008) Développement, compétitivité économique et emploi. Paris, Centre d'Analyse Stratégique, Mission Abraham "Pour une régulation durable du transport routier de marchandises": $79 \mathrm{p}$

5. Betard P (1977) La productivité dans les transports routiers de marchandises, définition et mesure, Thèse d'Etat, Université Paris IX Dauphine, U.E.R. Science des Organisations

6. Boltanski L, Thévenot L (1991) De la justification. Les économies de la grandeur. Paris, Gallimard (On Justification. The Economies of Worth, 2006, Princeton University Press)

7. Bureau of Transportation Statistics (1999) Transportation satellite accounts: a new way of measuring transportation services in America. US Department of Transportation, Washington

8. Burmeister A, Djellal F (2004) L'impact des technologies de l'information et de la communication sur l'organisation spatiale des activités de services, Cahiers de l'économie de l'innovation, $\mathrm{n}^{\circ} 19$, janvier

9. Burmeister A, Lefebvre L, Meunier C, Djellal F (2007) Logiques de performance dans le transport routier de marchandises, une approche par filières productives. Research report GRRT, Lille
10. Chow $\mathrm{G}$ et al (1995) Logistics performance: definition and measurement. Int J Phys Distrib Logist Manag 24:17-28

11. Diewert WE (1992) The measurement of productivity. Bull Econ Res 44(3):163-198

12. Djellal F (2001) Les trajectoires d'innovation dans les entreprises de transport routier de marchandises. Revue Française de Gestion $\mathrm{n}^{\circ} 33$.

13. Djellal F, Gallouj F (2008) The innovation gap and the performance gap in service economies: a problem for public policies. The Spirit of Innovation III Forum: Innovative Networks, Tacoma, Washington, USA

14. Doyle D (1998) Performance measure initiative at the Texas Department of Transportation. Transp Res Rec 1649:124-128

15. Du Tertre C (1999) Activités immatérielles, subjectivité et productivité. Groupe de Recherche "Régulation, Secteurs et Territoires". Paris

16. Du Tertre C (2007) «Modèle industriel» et «modèle serviciel» de performance, 17th International RESER Conference, Tampere (Finland), september

17. Fritsch R, Prud'homme R (1996) Le transport de marchandises: comment mesurer le service rendu ? Rev Rexecode 50:5-71

18. Gacogne V, Tweddle G, Viegas J, Mesquita R (1998) Quality of service in transport, EU project SOFTICE, Task 3, Bruxelles

19. Gadrey J (1991) Le service n'est pas un produit: quelques implications pour l'analyse économique et la gestion. Politiques et Management Public 9(1)

20. Gadrey J (1996) Services: la productivité en question. Desclée de Brouwer, Paris

21. Gadrey J, Gallouj F (2002) Productivity, innovation and knowledge in services, new economic and socio-economic approaches. Edward Elgar, Cheltenham

22. Gallouj F (1999) "Les trajectoires de l'innovation dans les services : vers un enrichissement des taxonomies évolutionnistes." Economie et Sociétés série EGS (Economie et Gestion des Services)

23. Gallouj F, Weinstein O (1997) Innovation in services. Res Policy 26:537-556

24. Griliches Z (1994) Productivity, R\&D and the data constraint. Am Econ Rev 84(1):1-23

25. Guilbault M, Gouvernal E, Soppé M (2008) Demand for transport and production systems - Shipper surveys in France in 1988 and 2004. European Transport Conference, Leeuwenhorst, The Netherlands, october

26. Hill P (1976) On goods and services. Rev Income Wealth 2:315338

27. Hill P (1999) Tangibles, intangibles and services: a new taxonomy for the classification of output. Canadian Journal of Economics 32 (2), april

28. Hipp C, Grupp H (2005) Innovation in the service sector: The demand for ser-vice-specific innovation measurement concepts and typologies. Res Policy 34(4):517-535

29. Kune B, Mulder N (2000) Capital stock and productivity in French transport, an international comparison, Conférence du CLERSE. The economics and socio-economics of services : international perspectives, Lille, juin

30. Lefebvre L (2006) Analyse des déterminants de la productivité dans le transport Routier de Marchandises. Une approche régulationniste, Unpublished working paper, INRETS-University Lille I

31. Meunier C, Lefebvre L, Burmeister A (2004) Logistic performance and development of the firms. World Conference on Transport Research, Istanbul, Juillet

32. Morana J, Paché G (2000) Supply chain management et tableau de bord prospectif: à la recherche de synergies. Logistique et Management 8(1):77-88

33. Oum TH, Waters WG, Yu C (1999) A survey of productivity and efficiency measurement in rail transport. J Transp Econ Policy 33:9-42 Par. 1 
34. PRTM, Cohen S, Roussel J (2002) Avantage supply chain, Edition d'organisation, coll performance/ qualité, Paris, septembre

35. Rémy A (2001) Evolution de la productivité globale du transport routier interurbain sur la période 1986-1998. In: Mulder N, Rémy A (eds) La productivité dans les transports, rapport SES, Paris, pp 70-80

36. Salini P (2003) Productivities, efficiencies and performance indicators in transportation, document de travail, Université Paris XII

37. Stapleton D (2002) Measuring logistics performance using the strategic profit model. Int J Logist Manag 13(1):89-107
38. Storper M, Salais R (1997) Worlds of production: the action frameworks of the economy. Harvard University Press

39. Talvitie A (1999) Performance indicators for the road sector. Transportation 26:5-30

40. Tretheway MW, Waters WG (1999) Comparing total factor productivity and price performance, concepts and applications to Canadian railways. J Transp Econ Policy 33:209220 Part 2

41. Vieira LFM (1992) The value of service in freight transportation, $\mathrm{PhD}$ thesis, Massachussets Institute of Technology, Boston 